\title{
Gambaran CT-Scan Tanpa Kontras pada Pasien dengan Batu Saluran Kemih di Bagian Radiologi FK Unsrat/SMF Radiologi RSUP Prof. Dr. R. D. Kandou Manado Periode Juli 2016 - Juni 2017
}

\author{
${ }^{1}$ Yanuar E. Tubagus \\ ${ }^{2}$ Ramli Haji Ali \\ ${ }^{2}$ Alfa G. Rondo
}

\author{
${ }^{1}$ Program Studi Pendidikan Dokter Fakultas Kedokteran Universitas Sam Ratulangi Manado \\ ${ }^{2}$ Bagian Radiologi Fakultas Kedokteran Universitas Sam Ratulangi Manado \\ Email: ytubagus96@gmail.com
}

\begin{abstract}
Urinary tract stone is the third most common disease after urinary tract infection and prostate cancer. Symptoms of urinary tract stones such as pain, hematuria, infection, fever, nausea, and vomiting appear when an obstruction occurs. To confirm the diagnosis of urinary tract stone, further examination can be performed such as radiology examination using CTScan which can provide a much better imaging compared to plain photo and ultrasonography. CT-scan is usually performed without contrast because the imaging of stone is clearly visible. This study was aimed to obtain the CT-scan imaging without contrast of patients with urinary tract stones in the Radiology Department of Faculty of Medicine Sam Ratulangi University/ SMF Radiology Prof. Dr. R. D. Kandou Hospital Manado in the period of July 2016 - June 2017. This was a descriptive retrospective study using patients' medical records at the Radiology Department. The results showed that there were 190 patients suffering from urinary tract stones. The majority of cases were males $(66.32 \%)$, age group of $48-57$ years $(30 \%)$, and had stones located in the renal region $(67.38 \%)$. Conclusion: Based on the CT-Scan examination without contrast performed on patients with urinary tract stones, the prevalence of urinary tract stone was higher in males and the age group of 48-57 years with the most common location of the stones in the renal region.
\end{abstract}

Keywords: urinary tract stones, CT-Scan without contrast

\begin{abstract}
Abstrak: Batu saluran kemih merupakan penyakit tersering ketiga setelah infeksi saluran kemih dan kanker prostat. Gejala batu saluran kemih muncul ketika terjadi obstruksi berupa rasa nyeri, hematuria, infeksi, demam, mual dan muntah. Untuk menegakkan diagnosis dapat dilakukan pemeriksaan lanjutan seperti pemeriksaan radiologi dengan menggunakan CT-Scan yang dapat memberikan hasil pencitraan yang lebih baik dibandingkan foto konvensional dan ultrasonografi. Pemeriksaan CT-Scan biasanya tanpa menggunakan kontras karena gambaran batu sudah tampak dengan jelas. Penelitian ini bertujuan untuk mengetahui gambaran CT-Scan tanpa kontras pada pasien dengan batu saluran kemih di Bagian Radiologi FK Unsrat/SMF Radiologi RSUP Prof. Dr. R. D. Kandou Manado pada periode Juli 2016 - Juni 2017. Jenis penelitan ialah deskriptif retrospektif menggunakan data sekunder dari rekam medis pasien di Bagian Radiologi. Hasil penelitian mendapatkan sebanyak 190 pasien yang menderita batu saluran kemih dengan proporsi paling banyak pada laki-laki (66,32\%), kelompok usia 48-57 tahun (30\%), dan lokasi tersering pada daerah ginjal (67,38\%). Simpulan: Berdasarkan hasil pemeriksaan CT-Scan tanpa kontras pada pasien batu saluran kemih didapatkan angka kejadian batu saluran kemih paling banyak pada laki-laki dan kelompok usia 48-57 tahun dengan lokasi tersering di daerah ginjal.
\end{abstract}

Kata kunci: Batu saluran kemih, CT-Scan tanpa kontras. 
Batu saluran kemih (Urolitiasis) adalah adanya massa keras di daerah saluran kemih yang masih belum diketahui penyebabnya secara pasti. Batu yang terbentuk merupakan kumpulan polycrystalline yang terdiri dari berbagai macam kristal dan matriks organik yang dapat menyebabkan obstruksi jika ukurannya cukup besar. Penyakit batu saluran kemih merupakan penyakit ketiga yang paling sering dijumpai setelah infeksi saluran kemih (ISK) dan penyakit patologik prostat. Gejala obstruksi dapat berupa rasa nyeri, hematuria, infeksi, demam, mual dan muntah. ${ }^{1-3}$

Berdasarkan penelitian sebelumnya, lokasi tersering batu saluran kemih terdapat di daerah ginjal atau ureter. ${ }^{4}$ Di Jerman 1$2 \%$ penduduknya mengalami batu ginjal setiap tahun sedangkan di Amerika Serikat terdapat $7 \%$ perempuan dan $13 \%$ laki-laki yang pernah mengalami batu ginjal dalam hidupnya. ${ }^{1}$ Berdasarkan hasil Riskesdas 2013, prevalensi batu ginjal di Indonesia sebanyak $0,6 \%$, dari data tersebut prevalensi tertinggi terdapat di DI Yogyakarta sebanyak 1,2\% dan paling sedikit di Bangka Belitung sebanyak $0,1 \%$. Untuk Provinsi Sulawesi Utara (Sulut) sendiri terdapat $0,5 \%$ kasus batu ginjal. ${ }^{5}$ Berdasarkan penelitian tahun 2016 oleh Pongsapan et al. ${ }^{6}$ di RSUP Prof Dr. R. D. Kandou didapatkan sebanyak 63 kasus batu ginjal dengan proporsi terbanyak pada laki-laki $(71,43 \%)$.

Terdapat banyak pemeriksaan penunjang untuk membantu menegakkan diagnosis batu saluran kemih, salah satunya ialah pemeriksaan radiologi dengan menggunakan CT-Scan. Menurut the European Society of Urogenital Radiology, pemeriksaan CTScan Urografi (CTU) merupakan alat pemeriksaan dengan hasil pencitraan yang lebih maksimal dibandingkan lainnya seperti foto konvensional dan ultrasonografi. Pemeriksaan CTU dapat dilakukan dengan atau tanpa menggunakan kontras namun untuk membantu penegakan diagnosis batu saluran kemih biasanya pemeriksaan tidak memerlukan kontras karena batu sudah dapat dilihat dengan jelas. ${ }^{7}$

Penelitian ini bertujuan untuk mengetahui gambaran CT-Scan tanpa kontras pada pasien batu saluran kemih di Bagian Radiologi FK Unsrat/SMF Radiologi RSUP Prof. Dr. R. D. Kandou periode Juli 2016 Juni 2017.

\section{METODE PENELITIAN}

Jenis penilitan yang digunakan ialah deskriptif retrospektif dengan menggunakan data sekunder berupa data rekam medis pasien di Bagian Radiologi FK Unsrat/ SMF Radiologi RSUP Prof. Dr. R. D. Kandou Manado periode Juli 2016 - Juni 2017. Data yang terkumpul kemudian dikelompokkan berdasarkan jenis kelamin, kelompok usia, dan lokasi batu pada saluran kemih.

\section{HASIL PENELITIAN}

Berdasarkan data yang terkumpul, didapatkan sebanyak 252 lembar permintaan pemeriksaan CT-Scan tanpa kontras dan terdapat 190 pasien dengan gambaran batu pada saluran kemih. Dari 190 pasien ditemukan sebanyak 126 pasien laki-laki $(66,32 \%)$ dan 64 pasien perempuan $(33,68 \%)$ (Tabel 1).

Tabel 1 Distribusi pasien berdasarkan jenis kelamin

\begin{tabular}{ccc}
\hline $\begin{array}{c}\text { Jenis } \\
\text { kelamin }\end{array}$ & n & $\begin{array}{c}\text { Persentase } \\
(\%)\end{array}$ \\
\hline Laki-laki & 126 & 66,32 \\
Perempuan & 64 & 33,68 \\
Total & 190 & 100 \\
\hline
\end{tabular}

Angka kejadian batu saluran kemih berdasarkan kelompok usia didapatkan terbanyak pada kelompok usia 48-57 tahun yaitu 57 pasien (30\%) dan kasus batu saluran kemih paling sedikit didapatkan pada kelompok usia $\geq 88$ tahun yaitu 1 pasien $(0,52 \%)$ (Tabel 2$)$.

Dari 190 pasien yang menderita batu saluran kemih ditemukan sebanyak 233 kasus dengan lokasi batu yang bervariasi yaitu di ginjal, ureter, dan kandung kemih. Hal ini dikarenakan dapat ditemukannya batu pada lebih dari satu lokasi saluran kemih. Lokasi batu saluran kemih paling sering ditemukan di daerah ginjal dengan 
jumlah 157 kasus $(67,38 \%)$, diikuti dengan batu di daerah ureter sebanyak 59 kasus (25,32\%), dan kandung kemih sebanyak 17 kasus $(7,3 \%)$. Pasien dengan batu di uretra tidak didapatkan (Tabel 3).

Tabel 2. Distribusi pasien berdasarkan usia

\begin{tabular}{ccc}
\hline $\begin{array}{c}\text { Usia } \\
\text { (tahun) }\end{array}$ & $\mathbf{n}$ & $\begin{array}{c}\text { Persentase } \\
(\boldsymbol{\%})\end{array}$ \\
\hline $18-27$ & 4 & 2,11 \\
$28-37$ & 13 & 6,84 \\
$38-47$ & 38 & 20 \\
$48-57$ & 57 & 30 \\
$58-67$ & 53 & 27,89 \\
$68-77$ & 20 & 10,53 \\
$78-87$ & 4 & 2,11 \\
$\geq 88$ & 1 & 0,52 \\
Total & 190 & $100 \%$ \\
\hline
\end{tabular}

Tabel 3 Distribusi kasus berdasarkan lokasi batu

\begin{tabular}{lcc}
\hline \multicolumn{1}{c}{ Lokasi } & N & $\begin{array}{c}\text { Persentase } \\
(\boldsymbol{\%})\end{array}$ \\
\hline Ginjal & 157 & 67,38 \\
Ureter & 59 & 25,32 \\
Kandung kemih & 17 & 7,3 \\
Uretra & 0 & 0 \\
Total & 233 & 100 \\
\hline
\end{tabular}

\section{BAHASAN}

Pada penelitian ini, dari 190 pasien dengan batu saluran kemih paling banyak dijumpai pada jenis kelamin laki-laki dibandingkan perempuan yakni sebanyak 126 kasus $(66,32 \%)$ dengan perbandingan 1,97:1. Hasil penelitian ini sejalan dengan penelitian yang dilakukan oleh Chand et al. ${ }^{8}$ di Tribhuvan University Teaching Hospital, Maharajgunj, Nepal dengan hasil perbandingan sebesar 1,35:1. Hal ini dikarenakan kadar kalsium dalam urin yang berperan dalam pembentukan batu lebih tinggi pada laki-laki dibandingkan pada perempuan, dan juga kadar sitrat yang berperan menghambat pembentukan batu lebih rendah pada laki-laki. Di samping itu terdapat pula peran hormon seks, yaitu hormon estrogen pada perempuan berperan sebagai peng- hambat agregasi garam kalsium, serta menurunkan ekskresi oksalat dan konsentrasi oksalat plasma. Berbeda halnya dengan hormon testosteron pada laki-laki yang memiliki peran berlawanan dengan hormon estrogen yaitu meningkatkan oksalat endogen yang kemudian memudahkan terjadinya kristalisasi. Anatomi saluran kemih juga memiliki peran penting pada pembentukan batu di mana pada laki-laki dengan saluran kemih yang lebih panjang dibandingkan perempuan memungkinkan terjadinya pengendapan substansi pembentuk batu lebih tinggi. ${ }^{9,10}$

Angka kejadian batu saluran kemih berdasarkan kelompok usia paling sering dijumpai pada kelompok usia 48-57 tahun sebanyak 57 pasien (30\%). Berdasarkan hasil penelitian ini, angka kejadian batu saluran kemih banyak dijumpai pada usia dekade keempat sampai dekade keenam. ${ }^{10}$ Pada beberapa kepustakaan, angka kejadian batu saluran kemih umumnya ditemukan pada usia 30-50 tahun yang selaras dengan hasil penelitian ini. ${ }^{9,11}$ Tingginya angka kejadian pada usia tersebut disebabkan oleh karena lebih rentannya seseorang mengalami gangguan peredaran darah seperti hipertensi dan kolesterol yang akan menyebabkan terjadinya pengapuran ginjal, agregasi kalsium oksalat dan kasium fosfat yang kemudian berubah menjadi batu pada saluran kemih. ${ }^{9}$ Selain itu, pada usia tersebut perkembangan ukuran tubuli proksimal mencapai ukuran maksimal yang kemudian menyebabkan terjadinya peningkatan kapasitas konsentrasi ginjal sehingga terjadi pula peningkatan kristalisasi pada lengkung Henle.10

Pada penelitian ini juga ditemukan gambaran batu saluran kemih di lokasi yang bervariasi yaitu ginjal, ureter, dan kandung kemih. Meskipun uretra masih merupakan organ saluran kemih, namun pada penelitian ini tidak ditemukan adanya gambaran batu di lokasi tersebut. Hal ini dikarenakan, pasien dengan batu uretra akan datang dengan gejala kandung kemih terasa penuh namun tidak dapat buang air kecil secara tiba-tiba, dan pasien kadang dapat meraba adanya batu di sepanjang penis. Kondisi ini 
termasuk kondisi yang membutuhkan tindakan segera untuk menghindari terjadinya komplikasi. Oleh karena itu, biasanya sudah tidak dilakukan pemeriksaan lanjutan lagi seperti pemeriksaan radiologi. Namun jika diperlukan dapat dilakukan pemeriksaan radiologi berupa foto polos abdomen atau USG. ${ }^{12}$

Berdasarkan hasil ekspertise pemeriksaan CT-Scan tanpa kontras, dari 190 pasien dengan batu saluran kemih paling sering dijumpai pada daerah ginjal yaitu sebanyak 157 kasus $(67,38 \%)$, diikuti dengan batu di ureter dan kandung kemih masing-masing sebanyak 59 kasus $(25,32 \%)$ dan 17 kasus (7,3\%). Ditinjau dari segi fisiologi, batu akan pertama kali terbentuk di ginjal karena ginjal merupakan organ ekskresi utama yang akan menghasilkan urin sebagai produk akhirnya. Apabila dalam urin terdapat zat yang bersifat promotor terhadap pembentukan batu dalam jumlah berlebih seperti kalsium, oksalat, dan fosfat maka akan terjadi kristalisasi yang kemudian berkembang menjadi batu. Batu di saluran kemih lainnya biasanya merupakan turunan dari batu ginjal. Dari segi anatomi, batu dapat ditemukan pada ureter, kandung kemih, dan uretra bila ukuran batu tersebut dapat melewati penyempitan pada ginjal sebelum memasuki ureter. Bila ukuran batu cukup besar $(>5 \mathrm{~mm})$ dapat menyebabkan terjadinya penyumbatan sehingga pada gambaran CTScan dapat ditemukan adanya pembengkakan baik pada ginjal maupun pada ureter. Hasil penelitian dari Partang ${ }^{11}$ mengenai evaluasi kasus batu saluran kemih di RS. Wahidin Sudirohusodo periode 2006-2010 menyatakan bahwa angka kejadian batu saluran kemih berdasarkan lokasi paling sering dijumpai pada daerah ginjal sebanyak 358 kasus (62\%) dan ureter sebanyak 131 kasus $(22,5 \%)$, yang sejalan dengan hasil penelitian ini.

\section{SIMPULAN}

Berdasarkan hasil penelitian yang dilakukan di Bagian Radiologi FK Unsrat/ SMF Radiologi RSUP Prof. Dr. R. D. Kandou Manado pada periode Juli 2016 -
Juni 2017 dapat disimpulkan kejadian batu saluran kemih paling banyak pada laki-laki dan kelompok usia 48-57 tahun dengan lokasi tersering di daerah ginjal.

\section{SARAN}

Disarankan untuk mensosialisasikan dan memberikan pendidikan kesehatan yang lebih baik dalam tatanan pelayanan kesehatan di rumah sakit.

Sangat disarankan untuk dilakukan penelitian lanjut mengenai batu saluran kemih karena penelitian ini masih kurang dilakukan di Indonesia.

\section{DAFTAR PUSTAKA}

1. National Center for Biotechnology Information. Kidney stone: overview. 2016 February 25 [cited 2017 August 6]. Available from: https://www.ncbi.nlm.nih.gov/ books/NBK348937/

2. Tanagho EA, McAninch JW. Smith's General Urology (16th ed). Singapore: Mc Graw Hill, 2004; p. 256-83.

3. National Institute of Diabetes and Digestive and Kidney Diseases. Definition and facts for kidney stones. 2017 May [cited 2017 August 6]. Available from: https://www.niddk.nih.gov/healthinformation/urologic-diseases/kidneystones/definition-facts

4. Hidayah ID, Nugroho T, Widianto A. Hubungan lokasi batu ureter dengan manifestasi klinis pada pasien ureterolithiasis di RSKB An Nur Yogyakarta. JKKI. 2013;5(2):97-105.

5. Balai Penelitian dan Pengembangan Kesehatan Kementerian Kesehatan RI. Riset Kesehatan Dasar, 2013; p. 94-5.

6. Pongsapan AGC, Tubagus VN, Loho E. Profil CT-Scan non kontras pada penderita nefrolitiasis di Bagian Radiologi BLU RSUP Prof. Dr. R.D. Kandou Manado periode 1 Januari-30 Agustus 2016 [Skripsi]. Manado: Fakultas Kedokteran Universitas Sam Ratulangi; 2017.

7. Uinarni H. Atlas USG \& CT-Scan Ginjal Normal dan Abnormal, Sugiarto L, editor. Jakarta: EGC, 2015; p. 32-3.

8. Chand RB, Shah AK, Pant DK, Paudel S. Common site of urinary calculi in kidney, ureter and bladder region. Nepal Med Coll J. 2013; 15(1):5-7. 
9. Ridwan MS, Timban JF, Ali RH. Gambaran ultrasonografi ginjal pada penderita nefrolitiasis di Bagian Radiologi FK UNSRAT BLU RSUP Prof. Dr. R. D. Kandou Manado periode 1 Januari - 30 Juni 2014. eCl. 2015;3(1):267-71.

10. Ratu G, Badji A, Hardjoeno. Profil analisis batu saluran kemih di laboratorium patologi klinik. Indonesian Journal of Clinical Pathology and Medical Laboratory. 2006;12(3):114-7.

11. Partang A. Evaluasi kasus batu saluran kemih RS Wahidin Sudirohusodo periode 2006-2010 [Makalah]. Makassar: Bagian Ilmu Bedah Fakultas Kedokteran Universitas Hasanuddin; 2011.

12. RSKB An Nur Yogyakarta. Pusat Pelayanan Urologi. [cited 2017 Nov 21]. Available from: http://www.annurhospital.com/ web/index.php?option=com_content\&v iew $=$ article $\& i d=115 \&$ Itemid $=134$ 